\title{
半乾燥キャベツの保存中における遊離アミノ酸, ビタミンCおよび一般細菌の変化
}

\author{
八木昌平*1§ $\cdot$ 枝川正樹*1 $・$ 乙黒親男*2 \\ 原 宏佳*1・金子憲太郎*1 \\ * 1 日本獣医応用生命科学大学 \\ *2 山梨県工業技術センター
}

\section{Changes in Free Amino Acid and Vitamin C Contents and Viable Bacterial Count of Half-Dried Cabbage during Preservation}

\author{
YAGHI Shouhei*1§, Egawa Masaki*1, Otoguro Chikao*2, \\ HARA Hiroyoshi*1 and KaneKo Kentaro*1 \\ * 1 Faculty of Applied Life Science, Nippon Veterinary and Life Science University \\ 2-27-5, Sakai, Musasino-shi, Tokyo 180-0022 \\ * 2 Comprehensive Research Organization for Science and Technology Yamanashi Prefectural Government \\ 2094, Out-machi, Koufu, Yamanashi 400-0055
}

We propose that half-dried cabbage is a very useful processed form of cabbage, because the appearance of its rehydrated form is almost the same as those of fresh cabbage; moreover, its microbial count showed no increase over a 3 -week preservation, its $\gamma$-amino butyric acid content tended to increase, and its vitamin $\mathrm{C}$ was held constant. To produce half-dried cabbage, shredded cabbage was dehydrated up to $70 \%$ its original weight by vacuum drying at 50 hpa at $50^{\circ} \mathrm{C}$. The dried cabbage was stored at -2 and $5{ }^{\circ} \mathrm{C}$. During 3 weeks of preservation, we analyzed the free amino acid and vitamin $\mathrm{C}$ contents of the cabbage once a week. We also measured the total bacterial and coliform counts, as well as the rehydration ratio of the sample immersed in water. The rehydration ratios of the dried cabbage samples preserved at 5 and $-2{ }^{\circ} \mathrm{C}$ decreased by $12.7 \%$ and $14.9 \%$, respectively, after 3 weeks. The dried sample stored at $-2{ }^{\circ} \mathrm{C}$ did not freeze even with more than 2 weeks of preservation, and the rehydrated form of this sample hardly differed from fresh cabbage in appearance. Throughout the storage at both 5 and $-2{ }^{\circ} \mathrm{C}$, the content ratio of glutamic acid to total amino acid decreased and that of $\gamma$-amino butyric acid content to total amino acid increased even though total amino acid content showed no change. Total vitamin $\mathrm{C}$ content seemed to remain unchanged, and the content ratios of both ascorbic acid and dehydroascorbic acid to vitamin $\mathrm{C}$ hardly varied throughout the preservation. The total bacterial and coliform counts of the dried sample hardly changed during preservation at both 5 and $-2{ }^{\circ} \mathrm{C}$.

(Received May 9, 2007 ; Accepted Nov. 28, 2007)

Key words: half-dried cabbage, free amino acids, vitamin $C$ contents, total bacterial count, coliform count 半乾燥キャベッ, 遊離アミノ酸, ビタミン $C$ 含量, 一般生菌数, 大腸菌群数

金子，八木ら ${ }^{1,2)}$ は，ハクサイとキャベツは低温蒸気 $\left(100^{\circ} \mathrm{C}\right.$ 以下) で加熱するとペクチン質の性状が変わり, そのことに由来する硬化現象が起こることを報告した。 また，グルタミン酸が減少し $\gamma$-アミノ酪酸の増加するこ
とも述べた。さらに，E. coliの培養液に浸漬後， $60^{\circ} \mathrm{C}$ の 蒸気で 5 分間加熱したブロッコリーはE. coliが陰性にな ったことも併せ報告した。

金子は低温蒸気での加熱工程に常圧または減圧下での

\footnotetext{
* 1 个180-0022 東京都武蔵野市境 2-27-5

$\S$ 連絡先 (Corresponding author) E-mail : shou@nvlu.ac.jp

* 2 テ 400-0055 山梨県甲府市大津町2094
} 
低温乾燥工程を連続させた技術を低温蒸気加熱加工法と して提案した ${ }^{124)}$ 。当該加工法は物質転換を伴う低温蒸 気加熱処理の工程と物理的転換の工程である低温乾燥を 連続させた新技術である。岐阜全農の岐阜アグリフーズ (株は低温蒸気加熱加工法による製造実機を敷設した野菜 工場を設立し現在はカット野菜, 半乾燥野菜, 乾燥野菜, 調味野菜, 冷凍調味野菜を製造出荷している。半乾燥野 菜は殺菌・洗浄または低温蒸気での加熱処理後に減圧ま たは常圧で加熱乾燥することにより水分を一部除去した 加工品であり, 凍結しにくく, $0{ }^{\circ} \mathrm{C}$ 以下での保存が可能 である。本報では殺菌・洗浄後に減圧下で歩留り70\%の 半乾燥状態にしたキャベッの保存中における遊離アミノ 酸, ビタミンCの変化を検討した。また, その保存性を 一般生菌数と大腸菌群の変化から検討した。

\section{実験方法}

\section{1. 供試キャベツ}

2006年の 9 〜 11月に東京都武蔵野市の野菜販売店から 購入したキャベツ（Brassica oleracea L. var. capitata L.)を用いた。

\section{2. キャベツの成型と洗浄}

約 $2 \mathrm{~mm}$ 幅の千切りキャベッを20倍量のpH 6.0 (酢酸 で調製), 次亜塩素酸ナトリウム溶液 $(\mathrm{NaClO}$ 溶液, 有 効塩素濃度 $150 \mathrm{ppm}$ ) に5 分間浸漬してから流水中で 5 分間水洗後に簡易脱水器（パール金属(株），東京）で 2 分 間脱水した。

\section{3 . 減圧加熱乾燥}

殺菌・洗浄・脱水した千切りキャベッを, 30 hpa, $50^{\circ} \mathrm{C}$ に調整した真空乾燥機（VOS-300 VD型，東

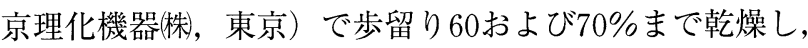
これらを半乾燥キャベッとした。試料 $300 〜 400 \mathrm{~g}$ を処理 した際の乾燥時間は $3 \sim 4$ 時間であった。

\section{4. 保存方法}

試料をポリプロピレン製の平袋に充填・シールしてか

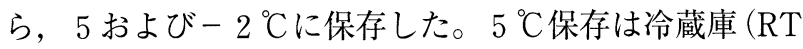
-150 SDC-ML型, ホシザキ電機(株), 東京), $-2{ }^{\circ} \mathrm{C}$ 保存 は恒温器 (LTI-700型, 東京理化機器(株), 東京) で行っ た。保存温度の $-2{ }^{\circ} \mathrm{C}$ はキャベツの水結点が，-1.3〜 $-2.2^{\circ} \mathrm{C}$ であるとの報告 ${ }^{5}$ を参考に設定した。

\section{5. 復元率の測定と透明感の評価}

半乾燥キャベツを生鮮物換算重量の 4 倍量の蒸留水に 浸漬した。ときどき攪拌しながら10２0分間放置した後 に脱水器で水切りしてから重量を測定した（復元重量）。 半乾燥キャベッは通常の乾燥野菜とは異なり, 水分の一 部除去に過ぎない。そのために, 復元率は, 生鮮物に対 する比率で表したほうがよいと考え, 供試半乾燥試料の 復元重量を供試半乾燥キャベツの生鮮物換算重量に対す る割合で表した（復元率＝復元重量／供試試料の生鮮物 換算重量 $\times 100)$ 。本研究は水戻しした後に生野菜と同様 な形での利用を目的にしているため,「透明感」は外観
的品質の低下を示唆すると考え, 復元したキャベッの 「透明感」の有無を目視により評価した。

\section{6 . 水分, 遊離アミノ酸, ビタミンCの分析}

水分は常法により減圧加熱乾燥法で測定した。遊離ア ミノ酸は裁断したキャベツを，10倍量の99.5\% EtOH で磨砕してから水を加えて, $80 \% \mathrm{EtOH}$ 濃度としてか ら還流抽出 $\left(80^{\circ} \mathrm{C}, 10\right.$ 分）を 3 回繰り返すことにより抽 出しだ)。万液を $40^{\circ} \mathrm{C}$ 以下で減压乾固してから0.02 M

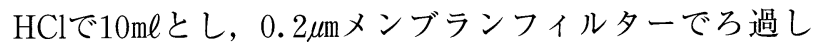
た。ろ液のアミノ酸をアミノ酸自働分析計（L-8500型,

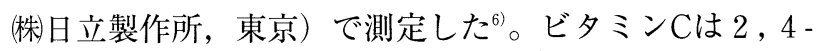
DNP法で測定した7)。

\section{7. 大腸菌群および一般生菌数の測定}

試料 $10 \mathrm{~g}$ を $90 \mathrm{~m} \ell の$ 滅菌生理食塩水に入れ, ストマッカ 一で 2 分間磨砕した懸濁液を試料原液とした。一般生菌 数は試料原液を標準寒天培地（栄研化学(株), 東京) で混 釈し $35^{\circ} \mathrm{C} て ゙ 48$ 時間培養し, 発生したコロニー数を測定し た。大腸菌群数は試料原液をデソキシコーレイト寒天培 地 (栄研化学(株), 東京) で混釈し, $35^{\circ} \mathrm{C} て ゙ 24$ 時間培養し, 発生したコロニー数を測定した。結果はCFU（Colony forming units)/gで表した。

\section{結果および考察}

\section{1. 半乾燥キャベツの復元率}

歩留り 60 および70\%に乾燥した半乾燥キャベツの浸漬 時間と復元率の変化をTable 1 に示した。

復元率は浸漬時間の経過に伴い高くなったが, 20分で ほぼ一定に達した。20分間浸漬したときの復元率は乾燥 歩留り 70\%が95.6\%, 60\%が90.5\%であり, 歩留りが高 いと復元率も高い傾向が認められた。

送風乾燥機（-0.5〜20 $\mathrm{C} ）$ で予措乾燥したホウレン ソウの復元 (約100\%) に要する時間は重量減少 $10 \%$ ま で乾燥した場合が 4 〜 時間， $20 \%$ では $5 \sim 8$ 時間， 30 \%では $12 \sim 18$ 時間である ${ }^{8), 9)}$ 。また, 水分含量が $6 〜 7 \%$ まで乾燥したニンジンでも, 浸漬時間が長くなるほど復

Table 1 Rehydration ratios of half-dried cabbage

\begin{tabular}{ccc}
\hline & \multicolumn{2}{c}{ Half-dried cabbage } \\
\cline { 2 - 3 } \begin{tabular}{c} 
Time for $\begin{array}{c}\text { rehydration } \\
\text { (min) }\end{array}$ \\
\cline { 2 - 3 }
\end{tabular} & \multicolumn{2}{c}{ Yield after dehydration $(\%)$} \\
\cline { 2 - 3 } 0 & $57.3 \pm 2.0$ & 70 \\
10 & $72.6 \pm 3.0$ & $88.6 \pm 0.9$ \\
15 & $84.0 \pm 3.5$ & $93.8 \pm 2.3$ \\
20 & $90.5 \pm 1.8$ & $95.6 \pm 1.4$ \\
25 & $91.5 \pm 1.0$ & $96.2 \pm 2.1$ \\
\hline Half-dried cabbage : & Shredded cabbage dehydrated by \\
vacuum drying at $50^{\circ} \mathrm{C}$ and 30 hpa up to 60 or $70 \%$ its \\
original weight. Rehydration ratio: Swelling ratio of half- \\
dried cabbage rehydrated by immersion in water.
\end{tabular}


Table 2 Changes in rehydration ratio and transparency of half-dried cabbage rehydrated in water

\begin{tabular}{|c|c|c|c|c|c|c|c|c|c|c|c|c|c|}
\hline \multirow{3}{*}{$\begin{array}{c}\text { Half-dried } \\
\text { cabbage } \\
(\%)\end{array}$} & \multirow{3}{*}{$\begin{array}{c}\text { Storage } \\
\text { temperature } \\
\left({ }^{\circ} \mathrm{C}\right)\end{array}$} & \multicolumn{12}{|c|}{ Storage period (weeks) } \\
\hline & & \multicolumn{3}{|c|}{0} & \multicolumn{3}{|c|}{1} & \multicolumn{3}{|c|}{2} & \multicolumn{3}{|c|}{3} \\
\hline & & $\begin{array}{c}\text { Moisture } \\
(\%)\end{array}$ & $\begin{array}{c}\mathrm{A} \\
(\%)\end{array}$ & $\mathrm{B}$ & $\begin{array}{c}\text { Moisture } \\
(\%)\end{array}$ & $\begin{array}{c}\mathrm{A} \\
(\%)\end{array}$ & B & $\begin{array}{c}\text { Moisture } \\
(\%)\end{array}$ & $\begin{array}{c}\mathrm{A} \\
(\%)\end{array}$ & B & $\begin{array}{c}\text { Moisture } \\
(\%)\end{array}$ & A & B \\
\hline $60 \pm 1.1$ & $\begin{array}{r}5 \\
-2 \\
\end{array}$ & $85.5 \pm 1.4$ & $89.2 \pm 1.3$ & - & $86.2 \pm 1.3$ & $\begin{array}{l}83.4 \pm 1.5 \\
84.3 \pm 2.0\end{array}$ & $T^{\top}$ & $84.3 \pm 1.8$ & $\begin{array}{l}80.3 \pm 1.5 \\
79.8 \pm 2.1\end{array}$ & $\begin{array}{l}- \\
+\end{array}$ & $86.1 \pm 0.9$ & $\begin{array}{l}77.3 \pm 1.5 \\
70.7 \pm 2.2\end{array}$ & $\begin{array}{l}- \\
+\end{array}$ \\
\hline $70 \pm 0.6$ & $\begin{array}{r}5 \\
-2\end{array}$ & $88.4 \pm 0.8$ & $95.5 \pm 2.1$ & - & $89.5 \pm 1.1$ & $\begin{array}{l}88.4 \pm 0.8 \\
88.0 \pm 1.8\end{array}$ & 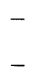 & $87.0 \pm 1.2$ & $\begin{array}{l}85.4 \pm 1.1 \\
85.9 \pm 0.5\end{array}$ & - & $87.2 \pm 0.5$ & $\begin{array}{l}82.8 \pm 1.7 \\
80.6 \pm 0.9\end{array}$ & $\begin{array}{l}- \\
+\end{array}$ \\
\hline
\end{tabular}

Half-dried cabbage and rehydration ratio: See Table 1.

A : Rehydration ratio. B: Transparency, appearance of half-dried cabbage rehydrated by immersion in water for 20 min.

$-:$ almost the same appearance as fresh cabbage. +: Transparent sample.

元率が高くなるとの報告 ${ }^{10)}$ がある。これらの報告から考 えて，乾燥歩留りは復元時間に影響を及ぼすと考えられ る。

Table 2 は半乾燥キャベッを 5 および $-2{ }^{\circ} \mathrm{Cに} 3$ 週間 保存した時の水分含量, 復元率と「透明感」である。復 元時間は20分とした。

半乾燥キャベツの水分は歩留り $60 \%$ が $85.5 \%$, 歩留り 70\%が88.4\%であり，保存中にほとんど変化しなかった。 また，データーとしては示さないが保存中の試料重量も 変化しなかった。水分含量が一定に保持されたことと, 重量の未変化は試料をプラスチック製の平袋に充填・シ 一ルして保存したためと考えられる。

歩留り $60 \%$ に乾燥した半乾燥キャベッの復元率は, $5{ }^{\circ} \mathrm{C}$ で 3 週間保存の場合，89.2\%から77.3\%に低下したが， 復元後の「透明感」はみられなかった。しかし, $-2{ }^{\circ} \mathrm{C}$ 保存では，復元率は89.2\%から70.7\%に低下した。ま た， 1 週間以上保存してから復元したキャべツには「透 明感」が観察された。ダイコンやハクサイの葉柄部は水 煮すると組織の透明化することが日常的な現象として認 識されている。水に浸漬した野菜を減圧状態にすると気 泡が発生する。また，ハクサイやキュウリの浅漬けを充 填液で袋詰めしてから $10^{\circ} \mathrm{C}$ で保存すると， 7 日目以後, 生野菜の不透明感をつくり出していた気体が充填液中に

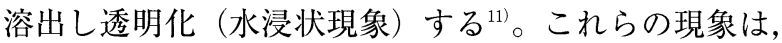
細胞間隙などに取り込まれている空気 ${ }^{12}$ が溶出した為と 考えられる。歩留り $60 \%$ の半乾燥キャベツを 1 週間以上 保存した試料には凍みることがなく，また，ドリップも なかったことから，水に浸漬したときの透明化は組織が 脱気されたことに起因する現象と思われた。

歩留り $70 \%$ に乾燥した半乾燥キャベッの復元率は, $5{ }^{\circ} \mathrm{C}$ で 3 週間保存の場合，95.5\%から $82.8 \%$ に低下したが, 復元後の「透明感」はなかった。 $-2{ }^{\circ} \mathrm{C}$ 保存では，復元 率は95.5\%から80.6\%に低下した。「透明感」は 2 週間 保存までは認められなかった。 3 週間保存した試料には 「透明感」が観察された。後述のFig.1の（4）でも示し たように試料はやや凍ったような状態であった。したが
って，「透明感」は凍みによると考えた。

以上のことから， $-2{ }^{\circ} \mathrm{C}$ で保存したキャべツの復元後 の透明感の有無, 復元率を考慮すると乾燥歩留りは70\% 程度が適切であると考えた。長時間浸漬することにより 復元率を高めることも可能であるが，本研究は中食・外 食等の食品産業で使用するカット・成型キャベッ（使用 期限 1 日）の保存性の延長も目的にしているので復元に 要する時間は30分以内が適当である。今後は復元する際 の成分の溶出についても検討する。

\section{2. 半乾燥キャベツの外観変化}

Fig. 1に- $2{ }^{\circ} \mathrm{C}$ に保存してから復元 (20分間) した $70 \%$ 半乾燥キャベッの写真を示した。写真には示していない が生鮮キャベツは24時間後には凍みていた。1 週間保存 （Fig.1（2）），および 2 週間保存（Fig.1（3））は生鮮 な千切りキャベッ（Fig.1（1））と外観や食感に差はな いと思われた。今後は, 食感についての官能検査を詳細 に行う予定である。 3 週間保存した半乾燥キャベッはや や凍った状態（Fig.1（4））であり，凍みと考えられた。

以上のことから， 2 週間保存後に復元したキャベッの 外観は新鮮物と遜色のないことが認められた。山根らは キャベツの氷結点は 3 枚目の葉が $-1.7^{\circ} \mathrm{C}, 30$ 枚目が$2.2{ }^{\circ} \mathrm{C}$ であり，全糖は各 $4.43 \% ， 5.26 \%$ あることから 氷結点と糖濃度は密接に関係していると述べている。供 試した半乾燥キャべツは，乾燥歩留りが70\%なので，キ ヤベッの水分 $(92.7 \%)$ のおよそ30\%を除去したことに なる。その結果, 遊離糖, 遊離アミノ酸などのエキス成 分の濃度が高まり, 水結温度が低下し, 生鮮物より凍結 しにくくなったと考えられる。したがって, 乾燥歩留り が低いと凍結しにくいが，乾燥しすぎると植物組織の脱 気に起因すると考えられる「透明感」が出る。「透明 感」は外観的な品質を損なうので, 生鮮物と同等な利用 を目的とする半乾燥野菜は，凍みや復元時の「透明感」 を生じない適切な乾燥歩留りを見いだす必要がある。

\section{3. 半乾燥キャベツの遊離アミノ酸の変化}

$70 \%$ 半乾燥キャベツを 5 およびー $2{ }^{\circ} \mathrm{C} に$ 保存したとき の遊離アミノ酸含量をTable 3 に示した。また，同条件 


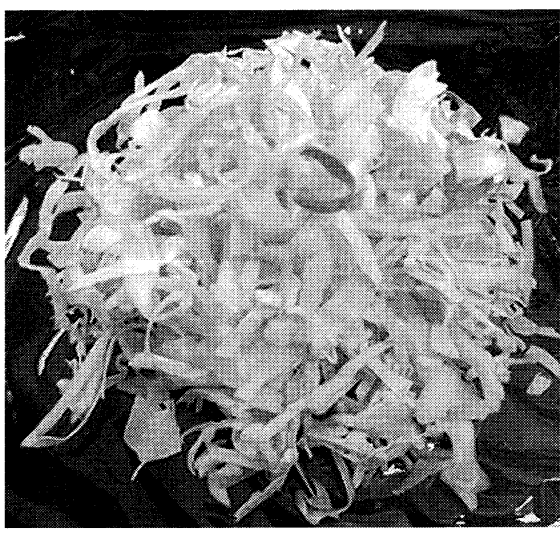

(1) Fresh cabbage

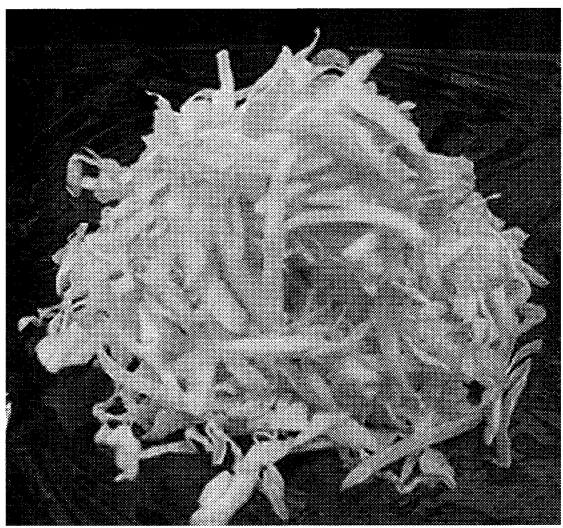

( 3 ) Rehydrated 2 weeks after storage

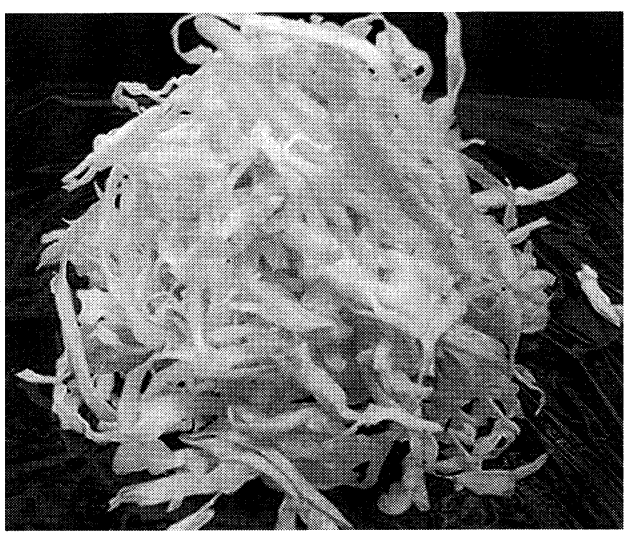

( 2 ) Rehydrated 1 week after storage

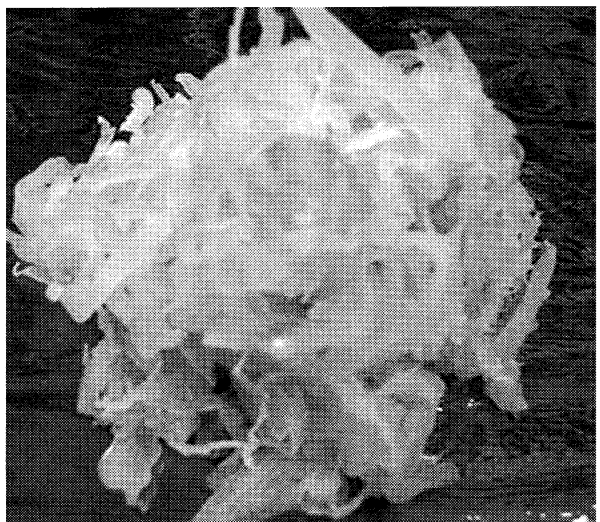

(4) Rehydrated 3 weeks after storage

Fig. 1 Changes in appearance of half-dried cabbage rehydrated after storage at $-2^{\circ} \mathrm{C}$

Half-dried cabbage: Shredded cabbage dried up to $70 \%$ its original weiht by vacuum drying at $50^{\circ} \mathrm{C}$ at 30 hpa. Rehydration was performed by immersing the half-dried cabbage for $15 \mathrm{~min}$ in water 4 times the volume in conversion weight of the dried cabbage.

Table 3 Changes in free amino acid contents of half-dried cabbage during storage at 5 and $-2^{\circ} \mathrm{C}$ for 3 weeks $(\mathrm{mg} / 100 \mathrm{~g}$, fresh weight)

\begin{tabular}{|c|c|c|c|c|c|c|c|c|c|c|}
\hline & \multirow{4}{*}{ Raw } & \multirow{2}{*}{\multicolumn{4}{|c|}{$\begin{array}{c}\text { Storage temperature } \\
5{ }^{\circ} \mathrm{C}\end{array}$}} & \multirow{4}{*}{ Raw } & \multicolumn{4}{|c|}{ Storage temperature } \\
\hline & & & & & & & \multicolumn{4}{|c|}{$-2{ }^{\circ} \mathrm{C}$} \\
\hline & & \multicolumn{4}{|c|}{ Storage period (Weeks) } & & \multicolumn{4}{|c|}{ Storage period (Weeks) } \\
\hline & & 0 & 1 & 2 & 3 & & 0 & 1 & 2 & 3 \\
\hline Asp & 26.2 & 38.2 & 21.5 & 11.3 & 10.6 & 39.5 & 41.9 & 25.7 & 18.6 & 19.4 \\
\hline Нyp & $t$ & 0.8 & 2.4 & 4.1 & 1.7 & $\mathrm{t}$ & 1.0 & 1.8 & 2.0 & 2.1 \\
\hline Thr & 7.3 & 8.9 & 8.9 & 8.9 & 11.8 & 9.9 & 14.5 & 18.7 & 16.2 & 15.8 \\
\hline Ser & 17.1 & 17.8 & 15.0 & 11.8 & 12.5 & 24.5 & 31.9 & 39.7 & 26.9 & 28.4 \\
\hline Asn & 28.3 & 44.2 & 38.5 & 28.7 & 35.0 & 38.2 & 55.6 & 63.5 & 48.5 & 50.2 \\
\hline Glu & 39.9 & 53.2 & 38.5 & 33.1 & 20.5 & 55.3 & 65.2 & 83.3 & 32.8 & 31.3 \\
\hline Gln & 108.0 & 162.5 & 132.5 & 121.0 & 116.3 & 133.2 & 209.8 & 211.3 & 150.0 & 172.7 \\
\hline Pro & 5.3 & 1.7 & 7.0 & 10.0 & 11.1 & 7.1 & 8.4 & 16.5 & 13.0 & 12.9 \\
\hline Gly & 1.8 & 2.4 & 3.2 & 3.5 & 10.9 & 2.4 & 3.4 & 3.1 & 5.8 & 4.9 \\
\hline Ala & 16.1 & 36.3 & 50.7 & 60.0 & 43.5 & 21.7 & 50.9 & 70.1 & 65.5 & 66.4 \\
\hline Cit & 0.4 & 0.6 & 0.7 & 1.7 & 0.9 & 0.6 & 1.2 & 1.2 & $t$ & 1.0 \\
\hline Val & 11.5 & 12.5 & 12.8 & 13.0 & 16.8 & 15.5 & 13.5 & 32.7 & 25.6 & 25.2 \\
\hline Cys & 0.7 & 0.9 & 2.0 & 1.2 & 2.8 & 0.9 & 1.9 & 2.0 & 2.4 & 1.9 \\
\hline Met & 0.3 & 0.5 & 0.5 & 0.7 & 1.0 & 0.4 & 0.6 & 1.1 & 1.1 & 1.2 \\
\hline Ileu & 5.7 & 6.9 & 6.8 & 6.1 & 9.3 & 7.7 & 10.2 & 16.3 & 12.8 & 12.4 \\
\hline Leu & 2.3 & 2.1 & 3.3 & 4.6 & 8.8 & 3.1 & 4.5 & 7.8 & 9.1 & 8.2 \\
\hline Tyr & 1.2 & 0.8 & 1.2 & 2.3 & 4.2 & 1.6 & 2.2 & 3.3 & 2.7 & 3.8 \\
\hline Phe & 3.2 & 2.1 & 2.4 & 3.3 & 6.0 & 4.3 & 5.0 & 10.1 & 8.9 & 8.4 \\
\hline GABA & 3.1 & 11.0 & 46.7 & 58.5 & 116.5 & 5.6 & 19.4 & 57.2 & 79.8 & 71.1 \\
\hline Orn & 0.1 & 0.2 & 0.4 & 0.3 & 0.5 & 0.2 & 0.2 & 0.3 & 0.2 & 0.2 \\
\hline Lys & 2.7 & 3.1 & 2.4 & 2.3 & 5.3 & 3.6 & 5.7 & 5.0 & 6.4 & 6.1 \\
\hline His & 12.8 & 16.1 & 10.3 & 16.7 & 18.0 & 17.3 & 20.0 & 26.8 & 20.7 & 21.0 \\
\hline Arg & 22.3 & 31.2 & 25.1 & 21.9 & 24.8 & 32.9 & 47.9 & 42.8 & 39.4 & 38.1 \\
\hline Total & 316.3 & 454.0 & 432.8 & 425.0 & 488.8 & 425.5 & 614.9 & 740.3 & 588.4 & 602.7 \\
\hline
\end{tabular}

GABA : $\gamma$-Aminobutyric acid. Half-dried cabbage: See Fig. 1. 
で保存した生鮮キャベツの結果をTable 4 に示した。

(1) 半乾燥処理による遊離アミノ酸の変化乾燥前 のキャベッ (千切りキャベッ) のアミノ酸総量は 316.3 $\mathrm{mg} / 100 \mathrm{~g}$ であった（Table $3,5{ }^{\circ} \mathrm{C}$ 保存)。構成アミノ酸 はグルタミン (Gln, 108.0mg)，グルタミン酸（Glu, $39.9 \mathrm{mg})$ ，アスパラギン (Asn, 28.3mg), アスパラギン 酸 (Asp, 26.2mg), アルギニン (Arg, 22.3mg) が多く, これらは総量の $71.0 \%$ 占めた。したがって，これら 5 種類を主要アミノ酸とした。 $\gamma$-アミノ酪酸（GABA）は $3.1 \mathrm{mg}$ と総量の $1.0 \%$ にすぎなかった。方，半乾燥キャ ベッ（Table $3 ， 5{ }^{\circ} \mathrm{C}$ 保存, 保存期間 0 ) のアミノ酸総 量は454.0mgを示した。乾燥歩留りが70\%なので生鮮物 換算含量は $317.8 \mathrm{mg}$ になり，原料キャベッの含量（316.3 mg）とほぼ同量である。また，総量に占める主要アミノ 酸合計量 $(329.3 \mathrm{mg})$ の比率 $(72.5 \%)$ は原料キャベッ のそれ $(71.0 \%)$ とほとんど変わらなかった。さらに， 各主要アミノ酸の構成比にも特別な変化が認められなか った。しかし，アラニン（Ala）は $16.1 \mathrm{mg} ら 36.3 \mathrm{mg}$ と 約 2 倍に増加した。アミノ酸総量に占める比率では $5.1 \%$ から8.0\%の増加である。GABAも $3.1 \mathrm{mg}(1.0 \%)$ が $11.0 \mathrm{mg}(2.1 \%)$ と微増する傾向が認められた。その他 のアミノ酸は数値的なバラツキはあるが, 顕著な変化を しないように思われた。

これらのことから, キャベッは半乾燥加工によってア ミノ酸総量と主要アミノ酸はほとんど変わらないがAla とGABAは微増する傾向が認められた。
（2） $5{ }^{\circ} \mathrm{C}$ で保存したときの遊離アミノ酸の変化 半 乾燥キャベッの $1 \sim 3$ 週間保存中のアミノ酸総量は 425.0〜 488. 8mgであった（Table $3 ， 5{ }^{\circ} \mathrm{C}$ 保存)。バラ ツキに一定の傾向の認められないことから，保存中にア ミノ酸総量はほとんど変化しないと考えた。最も多いGln (162.5mg) は 1 週間目に $132.5 \mathrm{mg}$ と減少し， 3 週間目は 116.3mgに減少した。Glu (53.2mg) も 1 週間後に38.5 $\mathrm{mg}, 3$ 週間後には $20.5 \mathrm{mg}$ と次第に減少した。また, Asp も微減の傾向が認められた。しかし，その他の主要アミ ノ酸（Asn,Arg）は数值の増減はあるがあまり変化しな いように思われた。GABA（11.0mg）は，1 週間後には $46.7 \mathrm{mg}$ と 4.2 倍に増加し， 3 週間後には $116.5 \mathrm{mg}$ と 10.6 倍 に増加した。Ala (36.3mg) は 2 週間目までは次第に増 加した $(60.0 \mathrm{mg})$ が， 3 週間後には減少した $(43.5 \mathrm{mg})$ 。 3 週間後のGABAはGlnとほほ同量であり, これらの合 計 $(232.8 \mathrm{mg})$ はアミノ酸総量の $47.6 \%$ 占めた。した がって, 半乾燥キャベッは保存中にGlnとGluがGABA とAlaに変化すると考えられる。

生鮮キャベツの 0 (新鮮物) 3 週間保存中のアミノ 酸総量は319.0〜386. $4 \mathrm{mg}$ であった（Table $4,5{ }^{\circ} \mathrm{C}$ 保 存)。值の増減に特定の傾向は認められないことからア ミノ酸総量はあまり変化しないと考えた。Gln（145.4 $\mathrm{mg})$ は， 1 週間後に126.5mgに減少し，3 週間後には $94.2 \mathrm{mg}$ と減少した。Glu（41.3mg）も 1 週間後には 31.3 $\mathrm{mg}, 3$ 週間後は $4.6 \mathrm{mg}$ と減少した。また，Aspも微減す る傾向が認められた。しかし, その他の主要アミノ酸

Table 4 Changes in free amino acid contents of cabbage during storage at 5 and $-2{ }^{\circ} \mathrm{C}$ for 3 weeks ( $\mathrm{mg} / 100 \mathrm{~g}$, wet basis)

\begin{tabular}{|c|c|c|c|c|c|c|c|}
\hline & \multirow{4}{*}{ Fresh } & \multicolumn{3}{|c|}{ Storage temperature } & \multicolumn{3}{|c|}{ Storage temperature } \\
\hline & & \multicolumn{3}{|c|}{$5^{\circ} \mathrm{C}$} & \multicolumn{3}{|c|}{$-2^{\circ} \mathrm{C}$} \\
\hline & & \multicolumn{3}{|c|}{ Storage period (Weeks) } & \multicolumn{3}{|c|}{ Storage period (Weeks) } \\
\hline & & 1 & 2 & 3 & 1 & 2 & 3 \\
\hline Asp & 30.8 & 11.4 & 9.4 & 10.7 & 13.4 & 11.4 & 15.2 \\
\hline Hyp & $t$ & 1.2 & 2.7 & t & 1.4 & 1.7 & 3.1 \\
\hline Thr & 7.6 & 5.7 & 7.6 & 8.3 & 10.7 & 9.7 & 9.7 \\
\hline Glu & 41.3 & 31.3 & 18.5 & 16.5 & 44.2 & 25.3 & 25.0 \\
\hline GIn & 145.4 & 126.5 & 111.7 & 94.2 & 101.1 & 116.5 & 136.9 \\
\hline Pro & 3.7 & 2.7 & 4.8 & 5.2 & 4.3 & 7.0 & 6.9 \\
\hline Gly & 2.3 & 2.5 & 4.1 & 8.1 & 2.3 & 3.5 & 3.3 \\
\hline Ala & 25.3 & 35.0 & 42.1 & 24.7 & 37.4 & 44.1 & 39.2 \\
\hline Ileu & 6.4 & 3.6 & 5.8 & 6.2 & 8.0 & 7.2 & 6.8 \\
\hline Leu & 2.0 & 2.0 & 4.5 & 5.8 & 4.0 & 3.6 & 3.0 \\
\hline Tyr & 0.8 & 0.8 & 2.6 & 2.8 & 1.1 & 1.4 & 1.6 \\
\hline Phe & 2.5 & 1.5 & 3.6 & 4.5 & 5.2 & 4.1 & 3.4 \\
\hline GABA & 4.7 & 19.7 & 40.1 & 80.3 & 27.3 & 41.6 & 41.0 \\
\hline Orn & 0.1 & 0.2 & 0.4 & 0.5 & 0.2 & 0.2 & 0.1 \\
\hline Lys & 3.9 & 1.4 & 2.6 & 3.8 & 2.5 & 3.0 & 2.7 \\
\hline His & 12.0 & 12.3 & 14.1 & 13.1 & 17.4 & 13.6 & 14.0 \\
\hline Arg & 31.5 & 13.9 & 17.7 & 20.6 & 25.2 & 24.8 & 27.2 \\
\hline Total & 386.4 & 319.0 & 343.4 & 361.5 & 379.1 & 393.0 & 410.6 \\
\hline
\end{tabular}

GABA : See Table 3. 
(Asn,Arg) はあまり変化しないように思われた。GABA $(4.7 \mathrm{mg})$ は， 1 週間後には4.2倍の $19.7 \mathrm{mg}, 3$ 週間後に は18.5倍の80.3mgと顕著に増加した。Ala (25.3mg) は 2 週間後 $(42.1 \mathrm{mg})$ までは増加した。 3 週間後はGln, GABAの合計（174.5mg）が総量の $48.3 \%$ 占めた。

したがって，キャベツは乾燥処理の有無にかかわらず $5{ }^{\circ} \mathrm{C}$ で保存すると, 遊離アミノ酸の総量はあまり変わら ないが, GlnとGluが漸減しGABAが顕著に増加するこ とと, Alaが 2 週間目までは増加することが認められた。

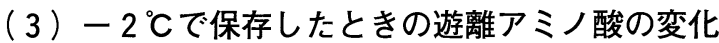
半乾燥キャベツの $1 \sim 3$ 週間保存中のアミノ酸総量は 588.4〜740.3mgであった（Table $3 ，-2{ }^{\circ} \mathrm{C}$ 保存)。值 の変動に一定の傾向が認められないことから, $-2{ }^{\circ} \mathrm{C} に$ おける $1 \sim 3$ 週間の保存中ではアミノ酸総量や最も量の 多いGln（209.8mg）はあまり変化しないと考えた。Glu $(65.2 \mathrm{mg})$ は，值にバラッキがみられるものの，3 週間 後には $31.3 \mathrm{mg}$ と減少した。また, Aspも微減の傾向が認 められた。しかし，その他の主要アミノ酸（Asn,Arg） は数值にバラッキはあるがあまり変化しないように思わ れた。GABA（19.4mg）は，1 週間後に57.2mg，2 週間 後に79.8mg と増加したが， 3 週間後にはほとんど変わら なかった。Ala (50.9mg) は 1 週間後に70.1mgと増加し， 保存の初期に増加する傾向が認められた。

これらのことから半乾燥キャべツは $-2{ }^{\circ} \mathrm{C} て ゙$ 保存する と, アミノ酸総量とGlnはあまり変化しないことがわか った。しかし, Gluは保存期間中に漸減し，GABAは 2 週間まで，Alaは 1 週間まで増加する傾向が認められた。

したがって, 半乾燥キャベツを 5 およびー $2{ }^{\circ} \mathrm{Cで} 3$ 週 間保存した場合, 共通の現象としてアミノ酸総量は変化 しないがGluの減少とGBAおよびAlaの増加することが 認められた。しかし， $5{ }^{\circ} \mathrm{C}$ 保存ではGlnも顕著に減少す ることが考えられた。

生鮮キャベッの $1 \sim 3$ 週間保存中のアミノ酸総量は 379.1〜410.6mgであった（Table 4, - $2{ }^{\circ} \mathrm{C}$ 保存)。バ ラツキはあるが, 量的な変化はあまり起こらないと考え た。Gln (145.4mg) は測定值にバラツキはあるが， $5{ }^{\circ} \mathrm{C}$ 保存と異なり, あまり変化しないように思われた。Glu (41.3mg) は, $5{ }^{\circ} \mathrm{C}$ 保存と同様に, 漸減し, 3 週間後は 25.0mgであった。また，Aspも微減の傾向が認められた。 その他の主要アミノ酸 (Asn, Arg) は数值にバラッキ はあるがあまり変化しないと考えた。GABA（4.7mg） は， 1 週間後には $27.3 \mathrm{mg}, 2$ 週間後には $41.6 \mathrm{mg}$ と漸増し たが， 3 週間後は $41.0 \mathrm{mg}$ と 2 週間後とほとんど変わらな かった。この傾向は $5{ }^{\circ} \mathrm{C}$ 保存（保存中顕著に増加）とは 異なっていた。また, Ala (25.3mg) は $5{ }^{\circ} \mathrm{C}$ 保存と同様 に2 週間まで増加する傾向が認められた。

生鮮キャベッの $-2{ }^{\circ} \mathrm{C} て ゙$ 保存におけるアミノ酸含量の 変化の傾向は半乾燥キャベッにおける傾向とほぼ同様で あった。

以上の結果, 半乾燥キャベツを保存すると, 生鮮キャ
ベッと同様に遊離アミノ酸の総量は変わらないが組成は 変化することが明らかになった。また, 組成の変化は $5{ }^{\circ} \mathrm{C}$ と $-2{ }^{\circ} \mathrm{C}$ 保存で異なるが, 各保存温度では, 生鮮キャべ ツと半乾燥キャベッで共通の傾向のあることが認められ た。この結果は, 乾燥条件（加熱温度, 時間, 減圧度) はアミノ酸の量と変化するアミノ酸の種類にはあまり影 響を及ぼさないことを示唆している。

ハクサイは塩漬けするとGluが減少しGABAが増加す る ${ }^{13)}$ 。また，茶葉は嫌気的条件で処理するとGluが減少 しGABAとAlaが増加する ${ }^{14), 15)}$ 。さらに, 茶葉は窒素ま たは炭酸ガス中で熟成するとGluがグルタミン酸デカル ボキシラーゼによりGABAに変化する ${ }^{16)}$ 。本実験の保存 は好気的条件ではあるが, $5{ }^{\circ} \mathrm{C}$ および- $2{ }^{\circ} \mathrm{C}$ 保存中のGlu の漸減とGABAの増加にはグルタミン酸デカルボキシラ 一ゼの関与する可能性が考えられた。今回の半乾燥処理 程度の加熱によって本酵素は失活しなかったと推察され た。今後は $0{ }^{\circ} \mathrm{C}$ 付近での本酵素の活性について検討する 必要があると考える。茶葉のGluは好気および嫌気的条 件でAlaに変化する ${ }^{15)}$ のでAlaの増加にGluの関与するこ とも考えられた。また, キュウリは貯蔵するとGluやAla が増加して味の好ましさが低下することから半乾燥キャ ベッの保存中のAla増加は鮮度の低下と関係するとも考 えた ${ }^{17), 18)}$ 。

キャベッと半乾燥キャベッの $5{ }^{\circ} \mathrm{C}$ 保存での $\mathrm{G} \ln$ の減少 の理由は, 保存中に袋の膨張はなかったが, ポリプロピ レン製の袋に無脱気で充填・シールしたことからキャベ ツの呼吸に由来する炭酸ガスによる保存環境の変化につ いても考える必要があるが今後の検討課題である。

\section{4. 半乾燥キャベツのビタミンCの変化}

生鮮キャベッと $70 \%$ 半乾燥キャベツを 5 および $-2{ }^{\circ} \mathrm{C}$ にそれぞれ保存した際のビタミンCの変化をTable 5 に 示した。

$5{ }^{\circ} \mathrm{C}$ 保存用に調製した半乾燥キャベツの総ビタミンC (TVC, 保存期間 0) は $46.4 \mathrm{mg}$, 生鮮物換算含量（乾燥 歩留り69.9\%）は32.4mgであった。キャベッのTVCは $29.9 \mathrm{mg}$ なの゙乾燥中に量的な変化をあまり起こさないと 思われる。また, 半乾燥キャベッの還元型ビタミンC (ASA) は $88.8 \%$, 酸化型ビタミンC (DHA) は $11.2 \%$, 生鮮キャベッは各89.3\%，10.7\%であったので, 乾燥中 にASAのDHAへの変化が起こらないと考えた。 $-2{ }^{\circ} \mathrm{C}$ 保存用に調製した半乾燥キャベッでもほぼ同様な傾向が 認められた。したがって, キャベッのビタミンCは乾燥 中に量および質的に安定に保持されると思われる。この ビタミンCの乾燥中の安定性は, 減圧下 (30 hpa) で, $50^{\circ} \mathrm{C}$ 程度の加熱であったためにビタミンCが酸化されにくか ったことに起因すると思われる。

$5{ }^{\circ} \mathrm{C}$ で保存した半乾燥キャベッのTVC $(46.4 \mathrm{mg})$ は, 3 週間後が $43.5 \mathrm{mg}$ であった。生鮮キャベッのTVC もほぼ同様の傾向を示した。したがって, 半乾燥キャべ ツのTVCは保存中に量的にほとんど変化しないと考え 
Table 5 Changes in vitamin $\mathrm{C}$ content of half-dried cabbage during storage at 5 and $-2^{\circ} \mathrm{C}(\mathrm{mg} / 100 \mathrm{~g}$, wet basis)

\begin{tabular}{|c|c|c|c|c|c|c|c|}
\hline \multirow{3}{*}{$\begin{array}{l}\text { Storageperiod } \\
\text { (Weeks) }\end{array}$} & \multirow[t]{3}{*}{ Sample } & \multicolumn{2}{|c|}{ ASAcontent } & \multicolumn{2}{|c|}{ DHAcontent } & \multicolumn{2}{|c|}{ TVCcontent } \\
\hline & & & & & & & \\
\hline & & 5 & -2 & 5 & -2 & 5 & -2 \\
\hline \multirow{3}{*}{0} & $\mathrm{~A}$ & $26.7(89.3)$ & $20.4(84.3)$ & $3.2(10.7)$ & $3.8(15.7)$ & $29.9(100)$ & $24.2(100)$ \\
\hline & B & $41.2(88.8)$ & $26.3(84.8)$ & $5.2(11.2)$ & $4.7(15.2)$ & $46.4(100)$ & $31.0(100)$ \\
\hline & Reducedvalue & 28.8 & 18.2 & 3.6 & 3.2 & 32.4 & 21.4 \\
\hline \multirow{3}{*}{1} & A & $30.8(92.8)$ & $26.7(83.4)$ & $2.4(7.2)$ & $5.3(16.6)$ & $33.2(100)$ & $32.0(100)$ \\
\hline & B & $39.1(90.7)$ & $37.7(79.7)$ & $4.0(9.3)$ & $9.6(20.3)$ & $43.1(100)$ & $47.3(100)$ \\
\hline & Reducedvalue & 27.3 & 26.1 & 2.8 & 6.6 & 30.1 & 32.7 \\
\hline \multirow{3}{*}{2} & A & $27.5(91.4)$ & $23.6(89.1)$ & $2.6(8.6)$ & $2.9(10.9)$ & $30.1(100)$ & $26.5(100)$ \\
\hline & B & $39.6(95.2)$ & $29.3(85.7)$ & $2.0(4.8)$ & $4.9(14.3)$ & $41.6(100)$ & $34.2(100)$ \\
\hline & Reducedvalue & 27.7 & 20.2 & 1.4 & 3.4 & 29.1 & 23.6 \\
\hline \multirow{3}{*}{3} & A & $25.3(82.1)$ & $31.1(82.3)$ & $5.5(17.9)$ & $6.7(17.7)$ & $30.8(100)$ & $37.8(100)$ \\
\hline & $\mathrm{B}$ & $30.9(71.0)$ & $41.5(86.5)$ & $12.6(29.0)$ & $6.5(13.5)$ & $43.5(100)$ & $48.0(100)$ \\
\hline & Reducedvalue & 21.6 & 28.7 & 8.8 & 4.5 & 30.4 & 33.2 \\
\hline
\end{tabular}

ASA : ascorbic acid. DHA : dehydroascorbic acid. TVC: total vitamin C. A : Shredded cabbage. B: Half-dried cabbage described in Fig. 1. Reduced value: vitamin $\mathrm{C}$ content of fresh cabbage calculated from the analytical vitamin $\mathrm{C}$ content of halfdried cabbage. ( ) : Content ratios of ASA and DHA to total vitamin C.

られる。しかし，ASAの比率 $(88.8 \%)$ は， 3 週間後 に71.0\%とやや低下するように思われた。生鮮キャベッ のビタミンCにもほほ同様な変化の傾向が認められた。

これらのことから生鮮キャベッと半乾燥キャベッのビ タミンCは $5{ }^{\circ} \mathrm{C}$ で保存すると保存期間中にTVCは変化し ないが, ASAは 2 週間以上の保存でDHAに変化する傾 向があると思われる。

- $2{ }^{\circ} \mathrm{C}$ で保存した半乾燥キャベッのTVC (31.0mg) は 1 週間後が $47.3 \mathrm{mg}, 2$ 週間後が $34.2 \mathrm{mg} ， 3$ 週間後が 48. $0 \mathrm{mg}$ であった。生鮮キャベッでの動向もほほ同様であ った。したがって, 半乾燥キャベッは $-2{ }^{\circ} \mathrm{C}$ 保存も, 測 定值の増減はあるが， $5{ }^{\circ} \mathrm{C}$ 保存と同様にTVCは安定に 保持されると考えられる。半乾燥キャベッのASAの比 率 $(84.8 \%)$ は， 3 週間後も $86.5 \%$ あ゙あ，ほとんど変 化しないように思われた。生鮮キャベッのビタミンCに も同様な傾向が認められた。

以上の結果， $-2{ }^{\circ} \mathrm{C} に$ 保存した半乾燥キャベッは $5{ }^{\circ} \mathrm{C}$ 保存に比べ，ビタミンCが質的に安定に保持されると考 えられる。

キャベッのビタミンCはゆで時間の長いほどゆで汁に 溶出するがキャベツとゆで汁中のビタミンCの合計量は 30分間ゆでても95\%以上が残存している ${ }^{19)}$ 。非加熱調理 や急速に加熱して組織の破壊以前にアスコルビン酸酸化 酵素が失活する調理ではビタミンCは安定に保持され る20)。キャべツは $-20^{\circ} \mathrm{C}$ で保存すると 5 日後にはASAが

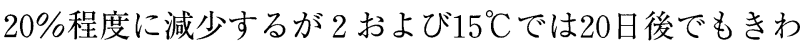
めて安定に保持される ${ }^{21)}$ 。また, $-20^{\circ} \mathrm{C}$ で保存したキャ ベッは $-80^{\circ} \mathrm{C}$ 保存に比べASAの分解が著しく大きいと
の報告 ${ }^{21}$ がある。この差異は, $-20^{\circ} \mathrm{C}$ は緩慢凍結22) なの で， $-80^{\circ} \mathrm{C}$ 保存より組織が崩壊しやすく, ビタミンCが 解凍時などに細胞に内在する遷移金属（鉄や銅等）のよ うな分解因子と接触しやすく, ASAが分解されやすい ためと考えられる。一方， $-2{ }^{\circ} \mathrm{C}$ はキャベッの水結点 付近の温度であるので組織が安定に保持され, 結果的に ASAが分解されにくいと考えられる。これらのことに ついては今後詳細に検討する。

以上のことから, 本実験でのTVCの安定性は保存温 度をその要因としてあげることができる。

以上の実験の結果， 5 抢よび- $2{ }^{\circ} \mathrm{C}$ に保存した半乾燥 キャベッはTVCが安定に保持されることが明らかにな った。しかし， $5{ }^{\circ} \mathrm{C}$ 保存では $-2{ }^{\circ} \mathrm{C}$ 保存に比べてASA が酸化されやすいと思われた。

\section{6. 半乾燥キャベツの保存中における一般生菌数と大腸 菌群数の変化}

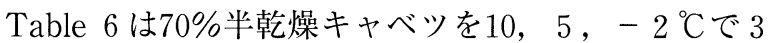
週間保存した際の一般生菌数と大腸菌群数の変化である。 各菌数は実数で表した。

調製直後の半乾燥キャベツは一般生菌数が $8.5 \times 10^{2}$ $\mathrm{CFU} / \mathrm{g}$, 大腸菌群が $<10 \mathrm{CFU} / \mathrm{g}$, 殺菌・洗浄直後の キャベッは各 $2.5 \times 10^{2} \mathrm{CFU} / \mathrm{g},<10 \mathrm{CFU} / \mathrm{g}$ であった。 $10^{\circ} \mathrm{C}$ 保存の半乾燥キャベッは保存中に一般生菌数, 大 腸菌群数ともに増加し， 3 週間後は各 $3.1 \times 10^{6}, 1.2 \times$ $10^{4}$ であった。キャベッは一般生菌数が次第に増加し 3 週間後には $1.3 \times 10^{7}$ と腐敗状態になった。同様に, 大腸 菌群も $7.8 \times 10^{4}$ に増加していた。

$5{ }^{\circ} \mathrm{C}$ 保存の半乾燥キャベッは 3 週間後の一般生菌数が 
Table 6 Changes in microbial counts of fresh cabbage and half-dried cabbage during storage at 10,5 and $-2^{\circ} \mathrm{C}$

\begin{tabular}{|c|c|c|c|c|}
\hline \multirow{2}{*}{$\begin{array}{l}\text { Storage period } \\
\text { (Weeks) }\end{array}$} & \multirow{2}{*}{$\begin{array}{c}\text { Storage } \\
\text { temperature }\left({ }^{\circ} \mathrm{C}\right)\end{array}$} & \multirow{2}{*}{ Sample } & \multicolumn{2}{|c|}{ Viable cell count (CFU/g ) } \\
\hline & & & Total bacterial count & Coliform count \\
\hline \multirow{2}{*}{0} & \multirow[t]{2}{*}{-} & Fresh & $2.5 \times 10^{2}$ & $<10$ \\
\hline & & Haf-dried & $8.5 \times 10^{2}$ & $<10$ \\
\hline \multirow{6}{*}{1} & \multirow[t]{2}{*}{10} & Fresh & $3.1 \times 10^{5}$ & $9.1 \times 10^{3}$ \\
\hline & & Haf-dried & $7.6 \times 10^{4}$ & $3.7 \times 10^{3}$ \\
\hline & \multirow[t]{2}{*}{5} & Fresh & $4.2 \times 10^{4}$ & $3.0 \times 10$ \\
\hline & & Haf-dried & $9.3 \times 10^{2}$ & $<10$ \\
\hline & \multirow[t]{2}{*}{-2} & Fresh & $1.1 \times 10^{3}$ & $<10$ \\
\hline & & Haf-dried & $7.1 \times 10^{2}$ & $<10$ \\
\hline \multirow{6}{*}{2} & \multirow[t]{2}{*}{10} & Fresh & $1.1 \times 10^{6}$ & $2.0 \times 10^{4}$ \\
\hline & & Haf-dried & $5.0 \times 10^{4}$ & $1.4 \times 10^{4}$ \\
\hline & \multirow[t]{2}{*}{5} & Fresh & $6.0 \times 10^{4}$ & $2.0 \times 10^{2}$ \\
\hline & & Haf-dried & $8.6 \times 10^{3}$ & $<10$ \\
\hline & \multirow[t]{2}{*}{-2} & Fresh & $6.0 \times 10^{2}$ & $<10$ \\
\hline & & Haf-dried & $8.0 \times 10^{2}$ & $<10$ \\
\hline \multirow{6}{*}{3} & \multirow[t]{2}{*}{10} & Fresh & $1.3 \times 10^{7}$ & $7.8 \times 10^{4}$ \\
\hline & & Haf-dried & $3.1 \times 10^{6}$ & $1.2 \times 10^{4}$ \\
\hline & \multirow[t]{2}{*}{5} & Fresh & $6.9 \times 10^{5}$ & $4.0 \times 10^{2}$ \\
\hline & & Haf-dried & $2.0 \times 10^{3}$ & $<10$ \\
\hline & \multirow[t]{2}{*}{-2} & Fresh & $1.5 \times 10^{3}$ & $<10$ \\
\hline & & Haf-dried & $2.2 \times 10^{2}$ & $<10$ \\
\hline
\end{tabular}

Half-dried cabbage: See Fig. 1.

$2.0 \times 10^{3}$ と調製直後とほとんど変わらなかった。また， 大腸菌群は＜10未満であった。キャベツは一般生菌数と 大腸菌群数が次第に増加したが $10^{\circ} \mathrm{C}$ 保存より少なかった。

$-2{ }^{\circ} \mathrm{C}$ 保存の半乾燥キャベツとキャベッは一般生菌数 と大腸菌群数がほとんど増加しなかった。

食品は水分活性が低下すると自由水が減るために微生 物が増殖し難くなり保存性が高まることが知られている。 半乾燥キャベッは，キャベッの水分 $(92.7 \%)$ のおよそ $30 \%$ 除去したことになる。水分活性の大幅な低下は期 待できないが自由水は幾分か減少する。したがって，一 般生菌数と大腸菌群の増殖抑制の一因に自由水の減少を 考えているが，今後詳細に検討する。また，氷温領域で は微生物の増殖が抑制される ${ }^{5), 23} 。-2{ }^{\circ} \mathrm{C}$ はキャベッの 氷結点よりやや低い温度 ${ }^{5}$ である。これらのことは, $2{ }^{\circ} \mathrm{C}$ で保存したキャベッの一般生菌数と大腸菌群が増殖 しないことの理由と考えた。こられの実験の結果から， 半乾燥キャベッは $5{ }^{\circ} \mathrm{C}$ 以下の保存であれば一般生菌数と 大腸菌が増殖し難いと考えられる。

以上の実験から，水分を $30 \%$ 程度除去して $-2 \sim 5{ }^{\circ} \mathrm{C}$ に保存した半乾燥キャベツは復元後の外観が生鮮物と遜 色のないことと菌の増殖を抑制し保存性向上の可能性が 示唆された。また, GABAが増加することとビタミンC
が安定に保持されることも判明した。実用上の保存温度 は, 成分の安定化と保存性を考慮して $-2{ }^{\circ} \mathrm{C}$ 前後が妥当 と考えられる。これにより中・外食産業で使用するカッ 卜・成型キャベツ（使用期限 $1 \sim 2$ 日）の安定的供給が 少なくとも 1 週間は可能になると考えられる。

\section{要 約}

減圧加熱乾燥することにより調製した歩留り $70 \%$ 半 乾燥キャベツを 5 およびー $2{ }^{\circ} \mathrm{Cに} 3$ 週間保存して復元率, 復元時の外観, 遊離アミノ酸, ビタミンCおよび一般生 菌数と大腸菌群数の動向を検討した。

(1) 3 週間保存した半乾燥キャベッの復元率は, $5{ }^{\circ} \mathrm{C}$ 保存では $12.7 \%$ 低下し, $-2{ }^{\circ} \mathrm{C}$ 保存では $14.9 \%$ 低下 した。

(2) 半乾燥処理はキャベッのアミノ酸組成と含量に大 きな変化を与えなかった。

(3) 半乾燥キャベツの保存中におけるアミノ酸の変化 の傾向は生鮮キャベッと同様であったが保存温度に よってグルタミン量に差異がみられた。

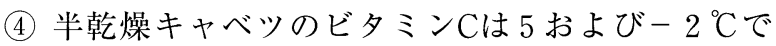
の保存中, 安定に保持された。

(5) 5 およびー $2{ }^{\circ} \mathrm{Cに}$ 保存した半乾燥キャベツは一般 
生菌数と大腸菌群数が 3 週間の間, ほとんど变化し なかった。

以上の結果から, 半乾燥キャベッは保存性が高く, ビ タミンCが保持され, 中・外食産業における生鮮キャべ ツの代替品となり得るとともに $\gamma$-アミノ酪酸の多い新規 食材として期待される。

\section{文献}

1 ) Kaneko, K., Otoguro, C., Kikuchi, S., Odake, S., Sumino, T., TsujI, K. and SaIto, K.: Changes in various ingredients, Escherichia coli, Taste and Texture of blade vegetables as a result of LowTemperature Steam-Heating process, Food Sci. Technol. Res., 5, 145 152 (1999).

2 ）八木昌平・乙黒親男・金子憲太郎：新技術としての 低温蒸気加熱加工法について一低温蒸気で加熱処理し た野菜は硬化して保存性も高まる一，日調科誌，38， 209 213 (2005)

3 ) Kaneko, K., Otoguro, C., Tsuji, K., Kikuchi, S., Odake, S., Sumino, T. and Cha H,- S. : Effect of the low-temperature steam-heating process on taste components, amino acids, cyanogenic glycosides, pectic substances an texture of ume fruit removed from liquor, Food preservation Science, 24, 95 101 (1998)

$4 ）$ 金子憲太郎 - 辻 匡子. 乙黒親男 - 小竹佐知子：野 菜を低温蒸気で加熱するとその特性がどのようにかわ るか, New Food Industry, 41 (12), 1 〜2（1999）

5 ) 山根昭美：氷温貯蔵食品の開発，日食工誌，29，736 $\sim 743$ (1982)

6 ) Kaneko, K., Otoguro, C., Yoshida, N., Utada, M, TsujI, K., KIKuchi, S. and Cha H,- S.: Influence of the Maturity of the Fruit Material on Various Components and Taste of Ume Liquor, Food Sci. Technol. Int, Tokyo, 4, 59〜65 (1998)

7 ）金子憲太郎：わかりやすい基礎食品分析法（前田安 彦・金子憲太郎編）（アイ。ケイコーポレイション， 神奈川), pp. 122 129（2004）

8 ）山下昭道・松田弘毅・松本道夫・安東一嘉：ホウレ ンソウの予措乾燥一復元技術の開発（第 1 報）一予措 乾燥及び復元条件について一，鳥取食品加工研究所報 告, 30, 18 24 (1989)

9 ）山下昭道・松本道夫・松田弘毅・安東一嘉：ホウレ ンソウの予措乾燥一復元技術の開発（第 2 報）一予措
乾燥 - 復元輸送実証試験, 鳥取食品加工研究所報 告, 31, $8 \sim 11$ (1991)

10) Quintero-Ramos, A., Bourne, M. C. and Anzaldua -MORALES, A. : Texture and Rehydration of Dehydrated Carrots as Affected by Low Temperature Blanching, J. Food Sci., 57, 1127 1130 (1992)

11）若林 昭・菊池久寿郎：加熱処理による浅漬けの日 持ち延長, 新潟県食品研究所報告, 19, 19 23（1983）

12）田村咲江：野菜・いも・果実類（田村咲江監修：食 品・調理・加工の組織学) (学空社, 東京), pp. 62〜 63 (1999)

13）高間総子・石井 潯・村木 繁：眝蔵による白菜漬 の品質変化，日食工誌，33，701７07（1986）

14) Tushida, T. and Murata, T.: Conversion of glutamic acid to $\gamma$-aminobutyric acid in tea leaves under anaerobic condition, Agric. Biol. Chem., 51, 2865 2871 (1987)

15）澤井祐典 - 許斐健一 - 小高保喜 - 吉冨 均 - 山口優 一・深山大介・竹内敦子：嫌気一好気交互処理による 茶葉の $\gamma$-アミノ酪酸量の増加, 食科工誌, 46, 462 466 (1999)

16）津志田藤二郎 - 村井敏信 - 大森正二 - 岡本順子 : $\gamma$ アミノ酪酸を蓄積させた茶の製造とその特徵, 農 化，61，817〜822（1987）

17）中町敦子・吉川光子・香西みどり・烟江敬子：キュ ウリ呈味成分の分布と貯蔵変化㧍よび味との関係, 日 調科誌，35，234 241（2002）

18）堀江秀樹 - 野菜の品質評価：野菜茶業研究集 報， 3，12 127（2006）

19）桐渕壽子：食品中のビタミンCの測定, 日調科 誌，28，210～216（1995）

20）桐㴊壽子・川嶋かほる：調理時におけるアスコルビ ン酸の変化，家政誌，38，877〜887（1987）

21）川村正純・浦部貴美子：低温保存に打ける野菜, 果 物中のアスコルビン酸の変動, 滋賀県立短期大学学術 雑誌，48，79〜82（1995）

22）グュエン・ヴァン・チュエン：食品加工学（倉田忠 男・松本信二編：食品加工学）(朝倉書店, 東京), pp. 27 30（1988）

23）上枝加代子 -大西茂彦：氷温貯蔵を利用したナス浅 漬の長期保存, 香川県産業技術センター研究報 告, $2,122 \sim 123$ (2002)

(平成19年 5 月 9 日受付，平成19年11月28日受理) 